\title{
導電塗膜電解システムによるフジッボ幼生の付着阻止
}

\author{
宇佐美正博*・北 村 等** \\ (平成 10 年 6 月 16 日受理)
}

\begin{abstract}
Prevention of barnacle settlement by electro-conductive coating system
Masahiro USAMI
\end{abstract}

Mitsubishi Heavy Industries, LTD., Nagasaki Research and Development Center

and

\section{Hitoshi Kitamura}

Faculty of Fisheries, Nagasaki University, Nagasaki 852, Japan

(Received Jun 16, 1998)

船舶や発電所の冷却水系および種々の海洋構造物に は, フジッボなどの海洋生物が付着繁殖し, 航走時の抵 抗増加や冷却効率の低下など様々な支障をきたしてい る。これらの付着防止対策として, 1990 年前半までは有 機スズ系の防污塗料が有効な手段として使用されてい た。しかし環境問題により，その使用が困難となった （杉田昭夫，1992）。そこで,これに代わるあのとして無 公害銼料の開発や電気化学的な付着防止法, あるいは超 音波の照射, さらには天然物由来の付着阻害物質の研究 などが行われている（電気化学会, 海生生物污損対策摡 談会, 1997)。

本報告では，導電塗膜による電解防污システム（西 昭雄ほか, 1991; 宇佐美正博・友重清美, 1995)について 検討した。このシステムは船や海洋構造物などに導電性 の塗料を塗装し，これに微少電流を流す方法でありこ の通電により海水が電気分解され, 陽極表面に次亜塩素 酸イオン $\left(\mathrm{ClO}^{-}\right)$を発生させて防污する方式である。し かし，ここで用いる導電性塗料はカーボンと有機系の樹 脂で構成されているため, その表面で発生する次亜塩素 酸イオンによって塗料が酸化し劣化する。塗膜の劣化は 通電量と関係があり, 導電塗膜の耐久性を考慮すると電 流量は必要最小限に設定する必要がある。

\footnotetext{
* 三菱重工 (株) 長崎研究所
}

** 長崎大学水産学部

Key words: 導電塗膜, 付着防止, 夕テジマフジッボ, 幼 生, 電流密度
海域実験では水質や付着生物の現存量などが種々異な るため, 付着生物を阻止するための有効な最少通電量を 求めることは困難であると考えられた。そこで，付着生 物の代表としてフジッボ幼生を用いての室内実験によ り, 効果的な通電量を検討した。

\section{実験方法}

フジッボとしては，本邦でも一般的な種類である夕テ ジマフジッボ (Balanus amphitrite) を用いた。本種のキ プリス幼生を用いた付着実験法としては，マルチウエル 法 (RITTSCHOF et al., 1984) や循環流水試験法 (KATSUYAMA et al., 1992; KITAMURA and NAKASHIMA, 1993) な どがある。後者の方法は，ポンプを用いた流水式の 2 種 類基盤の選択試験であり，幼生が付着しにくいナイロン 製の網生け筫を試験容器としたこと, 海水が循環するこ とにより流水条件となっていることなどの特徴を持つ。 本実験では, 循環流水試験法を採用したが, 通電により 発生する次亜塩素酸イオンを系外に排出する必要がある ため, 循環しつつ, 順次新鮮な海水之交換する方法とし た。

付着実験装置を Fig. 1 に示す。装置は三菱重工業(株) の長崎研究所内に設置した。容量約 $30 l$ の水槽に, 付着 実験の容器としてプランクトンネット（目合い $96 \mu \mathrm{m}$, ナイロン製）を用いて作成した網生け筫 $(4.7 l)$ を設置 した。これに9枚の試験基盤を垂下し，さらにキプリス 幼生を収容し, 海水を循環させっつ順次海水を交換し 


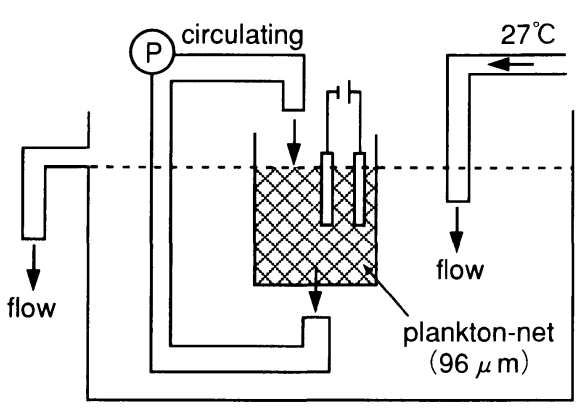

Fig. 1. Schematic view of the assay tank.

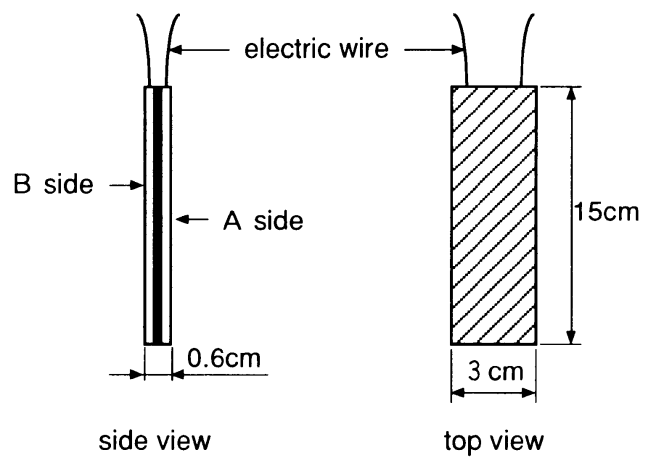

Fig. 2. Schematic view of the test piece. The polymethylmethacrylate plate is coated both sides ( $\mathrm{A}$ and $\mathrm{B}$ ) by the electro-conductive paint.
た。なお，この海水は隣接する長崎港より揚水し，ネッ 卜濾過および砂濾過を行なったものであり, 約 $200 l$ の 予備水槽に収容し, ヒータにて $27^{\circ} \mathrm{C} \pm 1{ }^{\circ} \mathrm{C}$ に調節した。 付着実験水槽への濾過海水の供給量はおよそ $500 \mathrm{ml} /$ 分 とした。この量は, 通電により発生した次亜塩素酸イオ ンが水槽内に残留しないように設定したあのであり, 随 時, 次亜塩素酸イオンを分析して残留していないことを 確認した。

上述の網生け筫水槽に試験基盤を合計 9 枚垂下した が，その基盤の概略を Fig. 2 に示す。試験盤の両面（A および B 面) には導電性の塗料が塗られており,これに 電線が取り付けられている。基盤 9 枚, 合計 18 面の垂下 方法を Fig. 3 に示す。9 枚は放射状に吊り下げられてお り, 隣の試験盤の相対する面 (A 面と B 面) を対として 通電した。これら相対する $\mathrm{A}$ 面と $\mathrm{B}$ 面との組み合わせ は, 合計 9 区画となるが, この 9 区画を無通電区と通電 区とに分け，また通電区も区画によっては電流密度を変 えて央験した。

通電量は, 電流密度として 0.1, 0.2, 0.3, $0.5 \mathrm{~A} / \mathrm{m}^{2}$ およ び $1.0 \mathrm{~A} / \mathrm{m}^{2}$ とした。また, 以上の連続通電実験とは別 に, 電流密度 0.1 および $0.2 \mathrm{~A} / \mathrm{m}^{2}$ については, 相対する $\mathrm{A}$ 面と B 面との極性を 2 時間おきに切り替える実験を あ行った。

試験盤をセットし種々の条件で通電した後, 直ちに本 種のキプリス奻生を 800 個体投入した。そして 3 日後に 各試験盤への幼生付着数を計測し， 1 面あたりの付着数 として算出した。なお, 本種幼生については, 浮游珪藻 Chaetoceros gracilis を与えて飼育し，5 日目にキプリス幼

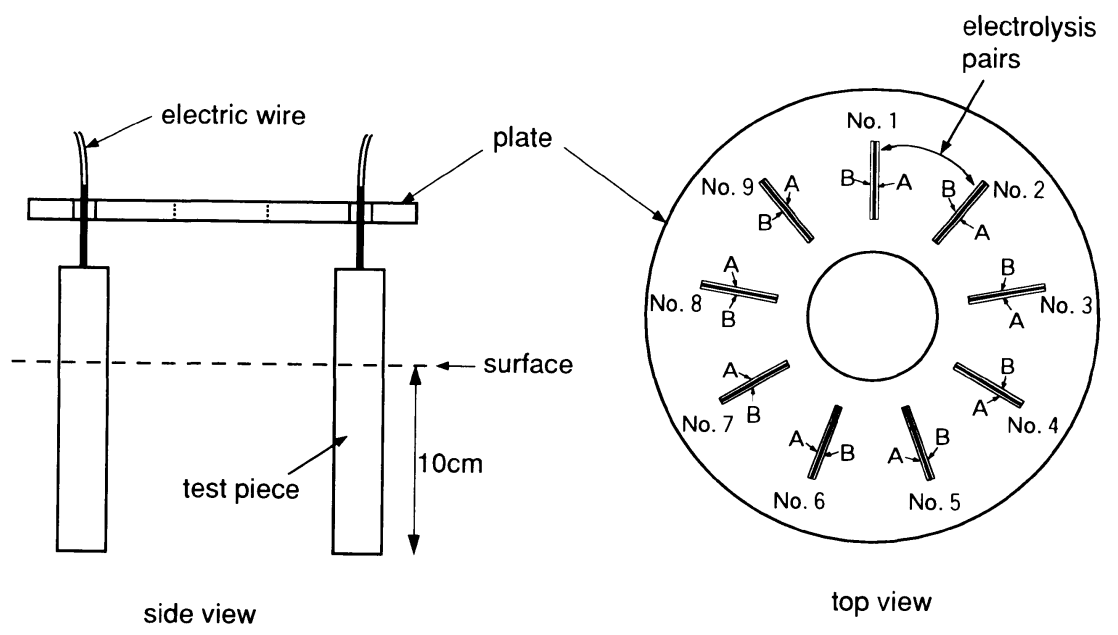

Fig. 3. Immersion of the nine test pieces in the plankton-net cage. 
生となったものを 1 日間冷蔵した後に実験に供した (Kitamura and NaKashima, 1996)。

\section{結果および考察}

タテジマフジッボ幼生に対する通電実験の結果を Table 1 に示す。表の最上部に示した電流密度 $0.1 \mathrm{~A} / \mathrm{m}^{2}$ の実験において，次亜塩素酸イオンが発生している陽極 (anode) 側では, 1 面当たりの平均稚フジッボ数は 0.5 個 体であったが, 無通電区では平均 9.2 個体であった。こ の両者の付着数の比（通電区の付着数/無通電区の付着 数）をとると, $0.05(0.5 / 9.2)$ となった。そして次亜塩素 酸イオンが発生していない陰極 (cathode) 側では稚フジ ッボ数は平均 4.2 個体であり，その比は 0.46 之なった。 この比が 1 に近いほど付着阻止効果は低く, 比が小さい ほど効果が大きいことになり，比が 0.5 であれば無通電 の場合に比べて付着数が半分ということになる。

電流密度 $0.1 \mathrm{~A} / \mathrm{m}^{2}$ の連続通電実験は他に 1 回行なっ たが，陽極面での付着数の比は $0.29(5.8 / 20)$, 陰極側で は $0.35(7.0 / 20)$ となった (Table 1)。さらに 2 時間ごと に陽極と陰極とを交換した実験は 3 回行ったが，無通電 区との付着数の比は各々 $0.19,0.43$ および 0.31 であっ た。

電流密度 $0.2 \mathrm{~A} / \mathrm{m}^{2}$ の連続通電実験は, 2 回行ったが, 陽極面で付着数の比は各々 0.12 と 0.03 であり, 陰極面 では各々 0.37 および 0.14 となった (Table 1)。陽極，陰 極の交換実験は合計 3 回行ったが，各々 $0.11,0.16$ およ び 0.02 となった。電流密度が $0.3,0.5$ および $1.0 \mathrm{~A} / \mathrm{m}^{2}$ の 実験では両極ともに，上述の電流量の実験と比較して全 体的に付着数の比は減少し， 0.01-0.16となった（Table 1)。

以上の実験を通して，陽極 (anode) 側では次亜塩素酸 イオンの発生で付着阻止効果は予想されていたが，陰極 (cathode) 側においても, 電流密度 $0.1 \mathrm{~A} / \mathrm{m}^{2}$ で付着数の 比が 0.46 および 0.35 , 電流密度 $0.2 \mathrm{~A} / \mathrm{m}^{2}$ で $0.37,0.14$ のごとく, 付着数が無通電区と比べて, 低下しているこ とが判明した（Table 1)。これは陰極表面では，溶存酸 素の還元反応により水酸基イオンを生成してアルカリ性 になっていたためと考えらる。したがって，陽極面より 防污効果は小さい傾向にあるものの陰極側であ防污効果 が期待できることが明らかとなった。

電流密度にともなう付着数の比を Fig. 4 に示す。電流 密度が上昇するに従い付着数の比が減少する傾向が認め られ, 電流密度が $0.1 \mathrm{~A} / \mathrm{m}^{2}$ では, 比は 0.05 から 0.46 で 推移しており, 無通電の場合に比べて付着数が半分以下
Table 1. The number of juvenile of the barnacle, Balanus amphitrite settled on electrified surfaces (anode and cathode) and none-electrified surfaces

\begin{tabular}{|c|c|c|c|}
\hline \multirow[b]{2}{*}{$\begin{array}{l}\text { Current } \\
\text { density } \\
\left(\mathrm{A} / \mathrm{m}^{2}\right)\end{array}$} & \multicolumn{2}{|c|}{ Number of juveniles/surface } & \multirow[b]{2}{*}{$\begin{array}{c}\text { Ratio of } \\
\text { settlement* }\end{array}$} \\
\hline & $\begin{array}{l}\text { Electrified } \\
\text { surface } \\
\text { (polarity) }\end{array}$ & $\begin{array}{l}\text { None- } \\
\text { electrified } \\
\text { surface }\end{array}$ & \\
\hline \multirow{2}{*}{0.1} & 0.5 (anode) & 9.2 & 0.05 \\
\hline & 4.2 (cathode) & 9.2 & 0.46 \\
\hline \multirow[t]{2}{*}{0.1} & 5.8 (anode) & 20 & 0.29 \\
\hline & 7.0 (cathode) & 20 & 0.35 \\
\hline \multirow[t]{3}{*}{0.1} & 3.8 (change $^{* *}$ ) & 20 & 0.19 \\
\hline & 3.9 (change) & 9.0 & 0.43 \\
\hline & 12 (change) & 39 & 0.31 \\
\hline \multirow[t]{2}{*}{0.2} & 1.1 (anode) & 9.0 & 0.12 \\
\hline & 3.3 (cathode) & 9.0 & 0.37 \\
\hline \multirow[t]{2}{*}{0.2} & 1.3 (anode) & 39 & 0.03 \\
\hline & 5.3 (cathode) & 39 & 0.14 \\
\hline \multirow[t]{3}{*}{0.2} & 1.0 (change) & 9.0 & 0.11 \\
\hline & 6.2 (change) & 39 & 0.16 \\
\hline & 0.8 (change) & 47 & 0.02 \\
\hline \multirow[t]{2}{*}{0.3} & 0.2 (anode) & 22 & 0.01 \\
\hline & 1.8 (cathode) & 22 & 0.08 \\
\hline \multirow[t]{2}{*}{0.5} & 1.7 (anode) & 14 & 0.12 \\
\hline & 2.3 (cathode) & 14 & 0.16 \\
\hline \multirow[t]{2}{*}{1.0} & 0.7 (anode) & 14 & 0.05 \\
\hline & 0.7 (cathode) & 14 & 0.05 \\
\hline
\end{tabular}

* Ratio of the settlement is calculated as follows; (number of settled barnacles on electrified surface)/ (that of none-electrified surface).

** Polarity was changed alternately every two hours.

に低下していた。また，2 時間ごとに陽極と陰極とを交 換した実験では，極性を固定した場合とほぼ同様の付着 阻止効果であると言える。したがって，今回の極性切り 替え方法では，固定極性と比べて，効果に大きな違いは ないと判断される。電流密度 $0.2 \mathrm{~A} / \mathrm{m}^{2}$ では, 付着比率は 0.02-0.37で推移したが，陰極の 0.37 を除くと，他は全 て無通電区の 2 割以下に減少していた。

以上の実験より, 電流密度 $0.1 \mathrm{~A} / \mathrm{m}^{2}$ の連続通電では 半分以下の付着数に制御することができ, 電流密度 0.2 $\mathrm{A} / \mathrm{m}^{2}$ では 2 割程度に減少させることが可能と判断され た。なお, 電流密度 0.5 および $1.0 \mathrm{~A} / \mathrm{m}^{2}$ では効果は大き いものの塗膜の少化が予想された。これらの結果を直ち に海域に適応するには，緒言で述べたように種々の問題 があるが, 今後は電流密度 0.1 および $0.2 \mathrm{~A} / \mathrm{m}^{2}$ を中心と して海域実験を行う必要があろう。 


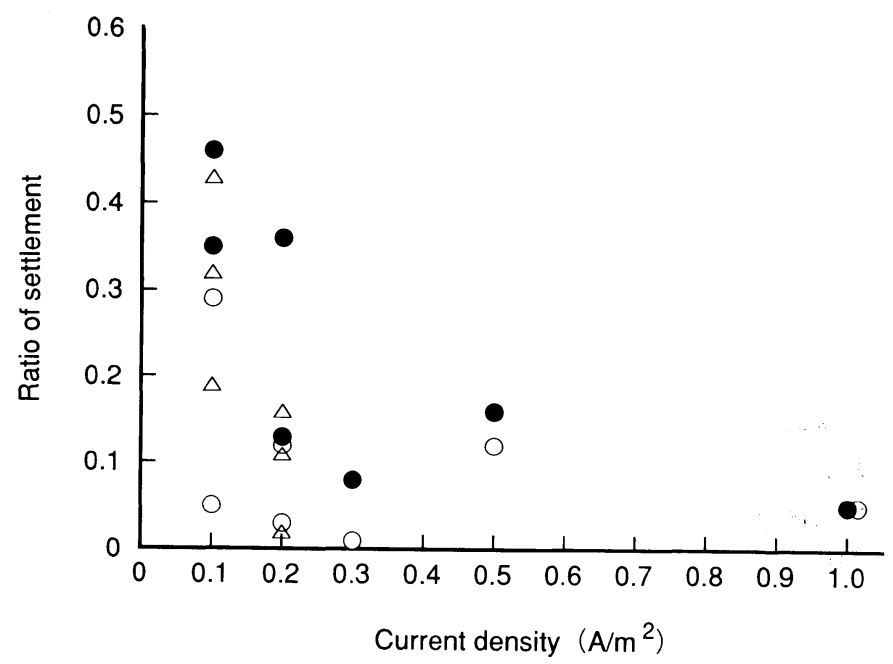

Fig. 4. Relationship between the current density and the ratio of settlement.

$\bigcirc$; anode, 0 ; cathode, $\triangle$; polarity was changed alternately every two hours.

\section{引用文 献}

Katsuyama, I., R. Kado, H. Kominami, and $H$. KitamuRA (1992). A screening method for test substances on attachment using larval barnacle, Balanus amphitrite, in the laboratory. Marine Fouling, 9, 13-14.

Kitamura, H., and Y. Nakashima (1993). Crude extracts of settlement factors from the barnacle Balanus amphitrite. OEBALIA, 16, Suppl., 609-612.

KitAmURA, H., and Y. NAKAShima (1996). Influence of storage temperatures and period on settlement rate and substrate discrimination in cyprids of the barnacle $\mathrm{Bal}$ anus amphitrite, Fisheries Science, 62, 998-999.

杉田昭夫 (1992). 問題の経緯と污染状況. 「有機スズ污染と水
生生物影響」（里見至弘・清水 誠編）, 恒星社厚生閣, 東 京, pp. 9-19.

電気化学会, 海生生物污損対策想談会 (1997). 無公害生物付着 防止対策シンポジゥム, 講演要旨集, pp. 1-246.

西 昭雄・宇佐美正博・植田健二・友重清美 (1991). 導電塗膜 による海洋生物付着防止技術の開発. 三菱重工技報, 28(3), $1-5$.

Rittschof, D., E. S. Branscomb, and J. D. Costlow (1984). Settlement and behavior in relation to flow and surface in larval barnacles, Balanus amphitrite DARWIN. J. Exp. Mar. Biol. Ecol., 82, 131-146.

宇佐美正博・友重清美 (1995). 導電塗膜による無公害海洋生物 付着防止システム. 日本造船学会誌, 795, 692-696. 